\title{
Analysing the Writing Skill Self-Efficacy of Students at English and German Language Teaching Departments
}

\author{
Bilal Üstün ${ }^{1}$ \\ ${ }^{1}$ School of Foreign Languages, Nevsehir Haci Bektas Veli University, Nevsehir, Turkey \\ Correspondence: Bilal Üstün, School of Foreign Languages, Nevsehir Haci Bektas Veli University, Nevsehir, \\ Turkey.
}

Received: September 16, 2021

Accepted: October 11, 2021

Online Published: October 13, 2021

doi: $10.5539 /$ elt.v14n11p30

URL: https://doi.org/10.5539/elt.v14n11p30

\begin{abstract}
This study set out to examine the writing skill self-efficacy of students studying at English and German Language Teaching Departments in terms of various variables. Survey model, one of the quantitative research methods, was preferred. Participants who study at English and German Language Teaching Departments at a university in Turkey were the samples of the research. 103 students, in total, participated in the research, and $62.1 \%$ of them were female and $37.9 \%$ of them were males. As the data collection instruments in the research, "self-efficacy scale of writing skills for foreigners learning Turkish as a second language" and "personal information form" were used. The scale had two dimensions as "expression and morphological characteristics of writing" and "using grammar rules in writing". As a result of the research, there were significant differences only in self-efficacy in using grammar rules dimension. In addition, female participants compared to males; participants studying German Language Teaching compared to English Language Teaching; and the fourth grade participants compared to the third grades were determined to have higher writing skill self-efficacy.
\end{abstract}

Keywords: writing skill, English language teaching, German language teaching, self-efficacy

\section{Introduction}

\subsection{Literature Review}

\subsubsection{Teaching Education}

Education is a concept that has been needed since the beginning of humanity. Thanks to education, societies have been able to interact and develop in economic, political, military and social fields. The most important factor in providing education to students successfully and in developing societies is undoubtedly the teacher. In all societies, teachers and the teaching profession are highly respected, and in some societies it is even considered as a sacred profession. Therefore, the concept of teacher has been the subject of many scientific studies and has been defined in different ways by different scientists. Çelikten et al. (2005, p. 208) defines teacher as a test taker, discipliner, defender of middle class morality, student counsellor, substitute parent and a reliable social participant. Moreover, Üstüner (2006, p. 110) describes teacher as a person who initiates, directs and facilitates the learning of individuals in line with a certain purpose in his study on teachers. When the literature is examined thoroughly, it is possible to find various definitions of the concept of teacher. For instance; Öncül (2000, p. 866) identifies the concept of teacher as the person assigned to guide and direct the learning experiences of students in a public or private educational institution; Çiçek Sağlam (2008, p. 60) states that the patient is what a person needs to constantly improve oneself and loves to working; and Mahiroğlu (2009; cited by Usta \& Korkmaz, 2010, p. 1137) as a person who implements education programs and determines the quality of education system and education services and as the responsible person for the success of the education system. The teachers who comply with the definitions above can be considered as qualified teachers. The qualification of teachers is certainly dependent on the education. The higher the quality of education pre-service teachers receive, the more the pre-service teachers can develop themselves and the more beneficial they can be to their students and society.

Similar to other professions, there are different branches in teaching profession. Although it is difficult to distinguish one branch from another, the increasing interest in foreign languages in today's circumstances has made foreign language teaching more attractive. Some of the particular reasons of the increase in the need and 
interest in foreign languages are explained as the technological developments and widespread use of social media (Burak \& Çörekçi, 2021; Işık \& Bahat, 2021; Yıldız, 2021; Yürektürk \& Coşkun, 2020). Accordingly, people especially care about their children getting a good foreign language education and they prefer schools with qualified foreign language teachers. One of the features necessary for being a qualified foreign language teacher is a good knowledge on language. In other words, qualified foreign language teachers should have a good knowledge of the grammatical structure of the language they teach and should know four skills of the language very well, and should have the ability to teach these skills. These skills are taught to prospective teachers during their university education.

\subsubsection{Language Skills}

There are four basic skills in addition to grammar knowledge of the language. These skills are reading skill, listening skill, speaking skill and writing skill. Reading and listening are skills that do not require productivity and focus on understanding the other side, while speaking and writing skills require productivity and enable one to transfer information to the other side. Since there is productivity in speaking and writing skills, it can be said that these two skills are more difficult than other skills. Besides these skills, grammar knowledge also plays an important role as it is very important in written language, though, grammatical errors can be tolerated in spoken language. Aytaş and Çeçen (2010, p. 79) also argue that besides reading, listening, speaking and writing, which are the basic skills of language, grammar is an area that concerns and covers all of these skills. Therefore, in order to transfer information, especially in written language, it is necessary to have a good grammar knowledge as well as four skills of the language. The language skills and grammar knowledge are tried to be defined below through the information obtained from the literature.

\subsubsection{Grammar Knowledge}

Grammar knowledge was derived from the Latin word "gramma" meaning "letter and sign" and the word "grammatica", defined as "the art of writing and reading letters" (Güneş, 2013, p. 73). Banguoğlu (1990, p. 19) describes grammar as a practical branch of knowledge that shows the correct way of writing, reading and speaking a language correctly; Ediskun $(1988$, p. 65) defines it as the scientific method of speaking and writing in a correct way. Grammar is a field of study that aids to think, speak and write accurately, and students reveal the possibilities, limits and hidden power of the language through learning grammar (Sever, 2000, p. 25). It is very difficult to express feelings and thoughts without grammar. In his study on grammar, Sağır $(2002$, p. 19) emphasizes that it is not possible to express thoughts and feelings accurately and completely without using grammar. In other words, having a good knowledge of four skills of the language can only be achieved by having a comprehensive knowledge of grammar.

\subsubsection{Reading Skill}

Reading skill, which is one of the four basic skills in foreign language teaching and of two skills for understanding, is also one of the two basic skills based on written language (Günday, 2015, p. 180). Reading is the activity of making sense of, comprehending, perceiving and seeing a text, sentences or words with all their elements (Sever, 2004, p. 78). While Güneş (2007, p. 117) expresses reading skill as a complex process in which physical and mental elements cooperate; Coşkun (2002; cited by Coşkun, 2003, p. 102) also states reading skill as different mental processes such as seeing, perceiving, paying attention, remembering, making sense, interpretation, synthesis and analysis occurring simultaneously; and as a very important educational tool that plays a role in gaining knowledge and culture, and reaching critical consciousness in order to get to know oneself, the environment and the world. Akyol $(2014$, p. 33) evaluates the communication aspect of reading skill and defines reading skill as a dynamic process that provides active and effective communication between the writer and the reader.

\subsubsection{Listening Skill}

Listening skill, as another basic language skill, is started to be used before birth (Doğan, 2010, p. 264). From this point of view, the language learning process starts by listening during pregnancy of mother; it forms the basis for speaking, reading and writing (Güneş, 2007, p. 73). Listening skill has been defined in different ways in the literature. Özbay (2006, p. 5) defines the listening skill as the ability to fully understand the message that a person is speaking or reading aloud; Göğüş $(1978$, p. 228), to pay attention to understand what one hears; Gürgen (2008, p. 49), to comprehend a message sent through speaking or reading; and Ergin and Birol (2000, p. 115) define it as a psychological process that starts with being aware of sounds and paying attention to them, continues with recognizing and remembering certain auditory signs, and ends with making sense of them. Listening skill is important not only in terms of understanding, learning, and developing mental, emotional and social skills, but also being a communication tool (Güneş, 2013, p. 80). 


\subsubsection{Speaking Skill}

The second skill after listening is the speaking skill. This skill can be developed by the support of environmental factors in almost every period of life, starting from the period after birth (Üzüm, 2021, p. 8). Speaking skill, which is the most basic skill in communication, is the transfer of thoughts, feelings and information to the other side through language consisting of sounds (Demirel, 1999, p. 40). Speaking skill is addressed in two ways in the text of the Common European Framework of Reference for Languages. One of these is conversation, which is defined as "participation in a conversation", and the other is "connected speech". The main purpose of the conversation is to communicate verbally in the target language, not to interrupt the communication and to ensure its continuation. In connected speech, the aim is to have uninterrupted speeches about a certain subject (Uysal, 2020, p. 14-15). According to Demirel (1999, p. 40), speaking skill has four basic characteristics: (1) Physical nature of speech: The process of propagation of sound waves in space (interference); (2) the physiological nature of speech: The process that occurs with the cooperation of organs such as the brain, nervous system, lungs, vocal cords, larynx, palate, lips and teeth in the human body; (3) the psychological nature of speech: Speaking directly about personal behaviours of the outside world; and (4) the social nature of speech: It is the way of communicating using spoken language. As one can see, speaking is a very complex skill that is realized through the help of many different factors.

\subsubsection{Writing Skill}

Writing skill is the last and the most difficult one to acquire among the four basic language skills, including listening, reading and speaking (Demir, 2013, p. 86) because the level of being competent and successful of the outputs of this skill in terms of accuracy and fluency is higher when compared to other language skills (Demir, 2013, p. 86). (Durmuş, 2013, p. 206). While the mistakes made at the time of speaking can be tolerated as long as the communication continues, it is more difficult to tolerate or overlook the mistakes in the written texts. Writing is a productive skill as speaking skill and it also has a communication dimension. According to Durmuş (2013, p. 206), writing is a narrative skill that explains thoughts using data such as examples, evidences; that aims to provide the basic written communication of daily life in some examples and to use an effective language in other examples; and during this process, it observes the strict spelling and punctuation rules of a standard language and the complex and various structures of grammatical knowledge. Akyol (2007, p. 146) also approaches the concept of writing skill in a similar understanding and defines writing as using the symbols and signs necessary to express thoughts in accordance with the rules and producing thoughts clearly. Considering the literature on writing skills, two approaches to writing skills are found out. One of these approaches is the product-based approach and the other is the process-based approach.

The product-based writing approach refers to the traditional writing approach that is learned by the readers based on examining the text and imitating the text they have studied during the learning process (Özdemir, 2019, p. 550). The process-based approach, on the other hand, is an approach that does not concentrate on the written product, but focuses mainly on the writing process (Ülper, 2008; cited by İpek, 2020, p. 26). Accordingly, writing skill among other basic language skills has a more complex structure and it takes more time to acquire than other skills.

\subsubsection{The Concept of Self-Efficacy}

The expression of self-efficacy was first introduced with the social learning theory developed by Albert Bandura in 1977 (Pamukoğlu, 2021, p. 22). Self-efficacy is the judgment about oneself that how successful an individual will be in overcoming the difficulties to be faced in the future (Senemoğlu, 2015, p. 234). Bandura, who introduced the concept of self-efficacy (1982, p. 122), defines the concept of self-efficacy as individual judgments about how well individuals can behave to cope with possible situations. Regarding the definition of the concept of self-efficacy, it can be said that this concept is very important for all people. Self-efficacy is also very important for teacher candidates because a teacher or teacher candidate with low professional self-efficacy will not have much to contribute to the profession and students.

\subsection{Purpose of the Study}

Bandura (2002; cited by Nazarl1, 2021, p. 10) states in his study that individuals with high self-efficacy will be successful in a duty they will do, while individuals with low self-efficacy will fail. In this context, this study set out to examine the writing skills self-efficacy of students studying at English and German Language Teaching Departments in terms of various variables. 


\subsection{Research Questions}

In this research, in which the writing skills self-efficacy of students studying at English and German Language Teaching Departments were examined, the following research questions were tried to be answered:

a. Does the self-efficacy of students studying at English and German Language Teaching Departments differ in terms of their departments?

b. Does the self-efficacy of students studying English and German Language Teaching Departments differ in terms of their gender?

c. Does the self-efficacy of students studying English and German Language Teaching Departments differ in terms of their grades?

\section{Methodology}

\subsection{Research Design}

In this study, the survey model, which is one of the quantitative research methods, was used. "Quantitative (empirical) researches use data collection techniques based on observation and experiment techniques, and conducted depending on the measurement of events and phenomena as an outside observer" (Tutar \& Erdem, 2020 , p. 60). The survey model, on the other hand, is a research approach that aims to describe a past or present situation as it is (Karasar, 2005).

\subsection{Participants}

The population of the research consisted of students of English and German Language Teaching Departments at universities in Turkey. The sample of the research consisted of students of English and German Language Teaching Departments at a university located in the Central Anatolian Region of Turkey. The participants study at the same university. Participants were randomly selected and all participants volunteered to contribute to the research. They were informed about the content and scope of the research by the researcher in advance. 103 students participated in the research. The frequency distributions of the sampling were presented in Table 1.

Table 1. Frequency distributions of the sampling

\begin{tabular}{lll}
\hline Variable & N & P(\%) \\
\hline Department & & \\
English Language Teaching & 54 & $52.4 \%$ \\
German Language Teaching & 49 & $47.6 \%$ \\
Gender & & \\
Female & 64 & $62.1 \%$ \\
Male & 39 & $37.9 \%$ \\
Grade & & \\
1. Grade & 28 & $27.2 \%$ \\
2. Grade & 24 & $23.3 \%$ \\
3. Grade & 25 & $24.3 \%$ \\
4. Grade & 26 & $25.2 \%$ \\
\hline
\end{tabular}

According to the data in Table 1, it was seen that $52.4 \%$ of the participants in the research were at the English Language Teaching Department and $47.6 \%$ of them were at the German Language Teaching Department. $62.1 \%$ of the participants were female and $37.9 \%$ were male. $27.2 \%$ of the group participating in the research were the first grade; $23.3 \%$ were the second; $24.3 \%$ were the third and $25.2 \%$ were the fourth grade students.

\subsection{Instruments}

"Writing self-efficacy scale for foreigners learning Turkish as a second language" developed by Kadir Kaan Büyükikiz (2012) and a personal information form prepared by the researcher were benefited as data collection instruments in the research. In the personal information form, the participants were asked questions about their departments, grades and genders. For foreigners learning Turkish as a second language, 16 questions were asked through the self-efficacy scale of writing skills. The scale was prepared in a 5-point Likert type. The options of the scale were determined as (1) Strongly Disagree, (2) Disagree, (3) Undecided, (4) Agree, and (5) Totally Agree. The scale consisted of 2 factors. These factors were specified as "expression and morphological 
characteristics of writing" and "using grammar rules in writing". The internal consistency coefficient of the scale, that is, the Cronbach Alpha $(\alpha)$ value, which is frequently used in psychological tests, was calculated as 0.93 for the first factor; 0.74 for the second factor; and 0.92 for the whole scale (Büyükikiz, 2012, p. 77). These results proved the reliability of the scale (Alpar, 2003; cited by Büyükikiz, 2012, p. 77). In this study, the Cronbach Alpha $(\alpha)$ value of the scale was calculated as 0.78 .

\subsection{Data Analysis}

For the analysis of the data in the research, IBM SPSS 21 package program was used. Statistics of the sample were calculated by frequency analysis. T-test and one-way analysis of variance (ANOVA) tests were utilized to determine the independent variables. The significance level was accepted as $\mathrm{p}<.05$ in all calculations.

\section{Findings}

In this part, whether the self-efficacy of the participants for writing skills was significantly different in terms of certain variables and were presented in tables. Post-Hoc Tukey test, one of the t-test and one-way analysis of variance (ANOVA) tests, was used in the analysis. The significance level in the analysis was accepted as $\mathrm{p}<.05$.

The t-test was employed to analyze whether the writing skill self-efficacy of the participants showed significant differences in terms of their departments. The results of the analysis were shown in Table 2.

Table 2. Statistics in terms of department variable

\begin{tabular}{lllllll}
\hline Dimension & Department & N & X & SD & t & p \\
\hline EMCW & English L. T. & 54 & 4.21 & .47 & 1.57 & \\
& German L. T. & 49 & 4.04 & .62 & 1.55 & .124 \\
UGRW & English L. T. & 54 & 2.39 & .84 & -5.76 & \\
& German L. T. & 49 & 3.41 & .94 & -5.74 & $.000^{*}$ \\
\hline *p<.05 & & & & & &
\end{tabular}

$* \mathrm{p}<.05$

According to Table 2, it was found out that in the dimension of "expression and morphological characteristics of writing", the writing skill self-efficacy of the participants was not significantly different in terms of department. However, significant differences were detected in the dimension of "using grammar rules in writing". According to the statistical data, it could be said that the self-efficacy of the students studying in the German language teaching department $(X=3.41)$ for using grammar rules in writing was higher than the students at English language teaching department $(\mathrm{X}=2.39)$.

Whether the writing skill self-efficacy of the participants differed significantly in terms of their gender was analyzed through the t-test and presented in Table 3.

Table 3. Statistics in terms of gender variable

\begin{tabular}{lllllll}
\hline Dimension & Gender & $\mathbf{N}$ & $\mathbf{X}$ & $\mathbf{S D}$ & $\mathbf{t}$ & $\mathbf{p}$ \\
\hline EMCW & Female & 64 & 4.18 & .54 & 1.29 & \\
& Male & 39 & 4.04 & .56 & 1.28 & .200 \\
\multirow{2}{*}{ UGRW } & Female & 64 & 3.05 & 1.05 & 2.28 & \\
& Male & 39 & 2.58 & .91 & 2.36 & $.020^{*}$ \\
\hline *p $<.05$ & & & & & &
\end{tabular}

When Table 3 was evaluated, it was determined that the writing skill self-efficacy of the participants did not differ significantly in terms of gender in the dimension of "expression and morphological characteristics of writing". Considering the dimension of "using grammar rules in writing", there were significant differences in terms of gender. It was found that the self-efficacy of female students $(X=3.05)$ in using grammar rules in writing was higher than male students $(\mathrm{X}=2.58)$.

The Post-Hoc Tukey test, one of the one-way analysis of variance (ANOVA) tests, was employed to assess whether the writing skill self-efficacy of the participants showed a significant difference in terms of their grades. Statistical results of the Post-Hoc Tukey test were shown in Table 4. 
Table 4. Statistics in terms of grade variable

\begin{tabular}{llllllll}
\hline Dimension & Grade & $\mathbf{N}$ & $\mathbf{X}$ & SD & Min. & Max. & $\mathbf{p}$ \\
\hline EMCW & 1 & 28 & 4.04 & .52 & 2.69 & 5.00 & \\
& 2 & 24 & 4.04 & .48 & 3.00 & 5.00 & \\
& 3 & 25 & 4.15 & .46 & 3.31 & 5.00 & \\
& 4 & 26 & 4.28 & .70 & 2.00 & 5.00 & .339 \\
UGRW & 1 & 28 & 2.64 & .18 & 1.00 & 4.67 & \\
& 2 & 24 & 3.00 & .19 & 1.67 & 5.00 & \\
& 3 & 25 & 2.57 & .16 & 1.67 & 5.00 & \\
& 4 & 26 & 3.32 & .24 & 1.33 & 5.00 & $.030^{*}$ \\
\hline
\end{tabular}

$* \mathrm{p}<.05$

According to Table 4, it was determined that there was not a significant difference on the writing skill self-efficacy of the participants in the dimension of "expression and morphological characteristics of writing" in terms of grade. Considering the dimension of "Using grammar rules in writing", significant differences were found in terms of grade. It could be said that the fourth grade participants $(X=3.32)$ had higher self-efficacy in using grammar rules in writing than the third-year participants $(X=2.57)$.

\section{Conclusion and Discussion}

This study set out to examine the writing skills self-efficacy of students studying at English and German Language Teaching Departments in terms of various variables. 103 students, in total, participated in the research, and $62 \%$ of them were female and $37.9 \%$ of them were male.

When the writing skills of the participants were examined in terms of gender variable, no significant difference was found in the dimension of "expression and morphological characteristics of writing", but significant differences were determined in favour of female participants in the dimension of "using grammar rules in writing". Accordingly, it could be concluded that the self-efficacy of female participants $(X=3.05)$ in using grammar rules while writing texts was more improved than male participants $(X=2.58)$. When the literature was examined, it was understood that Altunkaya and Ateş (2017, p. 94) obtained similar results in their studies, and found out that the writing skills self-efficacy scores of female participants were higher than the male participants. Kılıç Avan and Kalenderoğlu (2019, p. 24) had different results in their studies that there were no significant differences in the dimensions of "expression and morphological characteristics of writing" and "using grammar rules in writing", and that gender was not an effective variable in writing skill self-efficacy.

When the writing skill self-efficacy of the participants was analysed in terms of department variable, it was seen that there was no significant difference in the dimension of "expression and morphological characteristics of writing". When the dimension of "using grammar rules in writing" was examined, significant differences were found in terms of department. It could be stated that the self-efficacy of the participants who received German language teaching education $(\mathrm{X}=3.41)$ for using grammar rules while writing texts was higher than the participants who received English language teaching education $(\mathrm{X}=2.39)$. Although a detailed literature analysis was carried out, no study was discovered about the writing skill self-efficacy in terms of department variable because the studies were generally conducted at Turkish, English or German departments and the departments were not compared to each other in the studies.

When the writing skill self-efficacy of the participants was analyzed in terms of grade variable, only the dimension of "using grammar rules in writing" differed significantly. According to the statistical results, the self-efficacy of the participants in the fourth grade $(X=3.32)$ for using grammar rules while writing texts was higher than the participants in the third grade $(X=2.57)$. However, no significant difference was found in the dimension of "expression and morphological characteristics of writing". Akpınar Dellal and Akın (2016, p. 27) obtained partially similar results in their study and determined that the participants in the fourth grade and the participants in the second grade had the highest the writing skill self-efficacy. Kılıç Avan and Kalenderoğlu $(2019$, p. 25) reached different results in their studies and emphasized that the grade variable did not differ significantly in both dimensions and therefore, the grade did not have an effect on the writing skill self-efficacy.

It is recommended that the writing skill course hours and course qualifications provided at faculties should be increased in order to improve the writing skill self-efficacy of the students at English and German language 
teaching departments; academicians should have in-service training on writing skills and conduct more scientific studies on the subject. Moreover, it is thought that it will be appropriate to conduct similar studies with larger sample groups.

\section{References}

Akpınar Dellal, N., \& Akın, B. (2016). Alman Dili Eğitimi Öğrencilerinin Öz Yeterlilik İnançları. Turkish Studies, 11(19), 19-30. https://doi.org/10.7827/TurkishStudies.10045

Akyol, H. (2007). Türkçe ilk okuma yazma ögretimi. Ankara: Pegem Yayınc1lık.

Akyol, H. (2014). Türkçe Öğretim Yöntemleri. Ankara: Pegem Akademi Yayınları.

Altunkaya, H., \& Ateş, A. (2017). Yabancı Dil Olarak Türkçe Öğrenenlerin Yazma Öz yeterlikleri ile Yazılı Anlatım Becerileri. Erzincan Üniversitesi Eğitim Fakültesi Dergisi, 19(3), 86-103. https://doi.org/10.21497/sefad.756090

Aytaş, G., \& Çeçen, M. A. (2010). Ana dili eğitiminde dil bilgisi öğretiminin yeri ve önemi. Türklük Bilimi Araştırmaları, (27), 77-89.

Bandura, A. (1982). Social Foundations of Thought and Action: A Social Cognitive Theory. Englewood Cliffs, NJ: Prentice Hall.

Banguoğlu, T. (1990). Türkçenin Grameri. Ankara: Türk Dil Kurumu Yayınları.

Burak, S., \& Çörekci, E. D. (2021). Okul Öncesi Müzik Eğitiminde Teknoloji Kullanımı: Antalya İlinde Nitel Bir Çalışma. Eğitim Teknolojisi Kuram ve Uygulama, 11(2), 375-395. https://doi.org/10.17943/etku.886609

Büyükikiz, K. K. (2012). Türkçeyi İkinci Dil Olarak Öğrenen Yabancılar İçin Yazma Becerisi Öz Yeterlilik Ölçeğinin Geliştirilmesi: Geçerlilik Ve Güvenilirlik Çalışması. Mustafa Kemal University Journal of Social Sciences Institute, 9(12), 69-80.

Çelikten, M., Şanal, M., \& Yeni, Y. (2005). Öğretmenlik mesleği ve özellikleri. Erciyes Üniversitesi Sosyal Bilimler Enstitüsü Dergisi, 1(19), 207-237.

Çiçek Sağlam, A. (2008). Müzik öğretmenliği bölümü öğrencilerinin öğretmenlik mesleğine yönelik tutumları. Yüzüncü Yll Üniversitesi Ĕ̈itim Fakültesi Dergisi, 5(1), 59-69.

Coşkun, E. (2003). Çeşitli değişkenlere göre lise öğrencilerinin etkili okuma becerileri ve bazı öneriler. Türklük Bilimi Araştırmaları, (13), 101-130.

Demir, T. (2013). İlköğretim öğrencilerinin yaratıcı yazma becerileri ile yazma özyeterlik algısı ilişkisi üzerine bir çalışma. Uluslararası Türkçe Edebiyat Kültür Eğitim (TEKE) Dergisi, 2(1), 84-114.

Demirel, Ö. (1999). İlköğretim Okullarında Türkçe Öğretimi. İstanbul: Millî Eğitim Bakanlığı Yayınları.

Doğan, Y. (2010). Dinleme becerisini geliştirmede etkinliklerden yararlanma. Türklük Bilimi Araştırmaları, (27), 263-274.

Durmuş, M. (2013). Yabancılara Türkçe öğretimi. Ankara: Grafiker Yayınları.

Ediskun, H. (1988). Türk Dilbilgisi. İstanbul: Remzi Kitabevi.

Ergin, A., \& Birol, C. (2000). Eğitimde İletişim. Ankara. Anı Yayınc1lık.

Göğüş, B. (1978). Orta Dereceli Okullarımızda Türkçe ve Yazın Eğitimi. Ankara: Gül Yayınevi.

Günday, R. (2015). Yabancı dil ögretiminde yaklaşımlar, yöntemler, teknikler ve multimedya araç ve materyalleri. Ankara: Favori Yayınları.

Güneş, F. (2007). Türkçe Öğretimi ve Zihinsel Yapılandırma. Ankara: Nobel Yayınları.

Güneş, F. (2013). Dil Bilgisi Öğretiminde Yeni Yaklaşımlar. Journal of Language and Literature, 2(7), 71-92.

Güneş, F. (2013). Türkçe öğretimi yaklaşımlar ve modeller. Ankara: Pegem A Yayınları. https://doi.org/10.14527/9786053644927

Gürgen, İ. (2008). Türkçe Öğretimi. Eskişehir: Anadolu Üniversitesi Yayınları.

İpek, S. (2020). An investigation on writing skills and writing anxieties of Somalian students learning Turkish as a foreign language. (Unpublished Master Thesis). Bursa Uludağ University, Bursa, Turkey.

Işık, M., \& Bahat, İ. (2021). COVID 19: Eğitimde Yeni Arayışlar. Üniversite Araştırmaları Dergisi, 4(1), 82-89. https://doi.org/10.32329/uad.797635 
Karasar, N. (2005). Bilimsel Araştırma Yöntemi. Ankara: Nobel.

Kılıç Avan, Ş., \& Kalenderoğlu, İ. (2019). Yabancı Uyruklu İlköğretim Öğrencilerinin Yazma Becerisi Öz Yeterliliklerinin Belirlenmesi: Kastamonu Örneklemi. Aydın Tömer Dil Dergisi, 4(1), 16-30.

Nazarl1, S. (2021). The relationship between self-efficacy and entrepreneurial tendency: Comparison of Turkish and foreign students. (Unpublished Master Thesis). İstanbul University, İstanbul, Turkey.

Öncül, R. (2000). Eğitim ve Eğitim Bilimleri Sözlüğü. İstanbul: MEB Yayınları.

Özbay, M. (2006). Türkçe Özel Öğretim Yöntemleri II. Ankara: Öncü Kitap.

Pamukoğlu, İ. (2021). Self-efficacy perceptions towards teaching profession of social studies teacher candidates (Balıkesir University sample). (Unpublished Master Thesis). Balıkesir University, Balıkesir, Turkey.

Sağır, M. (2002). Türkçe Dil Bilgisi Öğretimi. Ankara: Nobel Yayın Dağıtım.

Senemoğlu, N. (2015). Gelişim, Öğrenme ve Öğretim: Kuramdan Uygulamaya. Ankara: Yargı Yayınevi.

Sever, S. (2000). Türkçe ögretimi ve tam ögrenme. Ankara: Anı Yayıncılık.

Sever, S. (2004). Türkçe öğretimi ve tam öğrenme. Ankara: Anı yayıncılık.

Tutar, H., \& Erdem, A. T. (2020). Bilimsel Araştırma Yöntemleri. Ankara: Seçkin Akademik ve Mesleki Yayınlar.

Usta, E., \& Korkmaz, Ö. (2010). Öğretmen adaylarının bilgisayar yeterlikleri ve teknoloji kullanımına ilişkin algıları ile öğretmenlik mesleğine yönelik tutumları. Uluslararası İnsan Bilimleri Dergisi, 7(1), 1335-1349.

Üstüner, M. (2006). Öğretmenlik mesleğine yönelik tutum ölçeğinin geçerlik ve güvenirlik çalışması. Kuram ve Uygulamada Ĕ̈itim Yönetimi, 45(45), 109-127.

Uysal, G. (2020). The effect of actual teaching techniques on prepared speaking skills of B2 level students learning Turkish as a foreign language. (Unpublished Master Thesis). Yıldız Teknik University, İstanbul, Turkey.

Üzüm, C. (2021). Examining speaking skills of midlle school 8th grade students in terms of variorus variables. (Unpublished Master Thesis). Siirt University, Siirt, Turkey.

Yıldız, Z. (2021). Uzaktan eğitimde teknoloji yönetimi. Journal of Sports Sciences, 2(2), 146-156. https://doi.org/10.29228/roljournal.52155

Yürektürk, F. N., \& Coşkun, H. (2020). Türkçe Öğretmenlerinin Teknoloji Kullanımına ve Teknoloji Destekli Türkçe Öğretiminin Etkililiğine Dair Görüşleri. Ana Dili Eğitimi Dergisi, 8(3), 986-1000. https://doi.org/10.16916/aded.748300

\section{Copyrights}

Copyright for this article is retained by the author(s), with first publication rights granted to the journal.

This is an open-access article distributed under the terms and conditions of the Creative Commons Attribution license (http://creativecommons.org/licenses/by/4.0/). 